\title{
Open To Support Accessibility: The Use of Open Books by SQU Faculty
}

\author{
K. Al Saadi
}

\section{ABSTRACT}

\begin{abstract}
With Sultan Qaboos University (SQU)'s growing strategic priorities to improve teaching and research performance while increasing their competitive edge and reducing costs, Open Educational Resources (OER) appear as a possible option where e-books are often cited to help streamline the SQU's resources and services. Similarly, the Instructional and Learning Technologies Program in the College of Education has an interest in the use of open books as a method of increasing accessibility to textbook materials for faculty and students. This descriptive study employed a survey to investigate $S Q U$ faculty uses and perceptions of open books to identify the advantages of increasing its accessibility. The analysis of the findings indicates that the faculty at SQU have access to open books and encourage positive experiences using them in their classrooms. That implicates a number of pedagogical benefits that can be supported by the use of open books. Therefore, it is important to grow the awareness among the policy makers and faculty about the benefits of encouraging and granting students access to other OER resources that might lead to more student learning.
\end{abstract}

Keywords: Accessibility, E-books, Higher Education, OER, Oman, Open Books, SQU

\section{INTRODUCTION}

Textbooks continue to be the primary medium for designing and delivering educational curriculum in most of the educational institutions around the globe (Jobrack, 2011; Robinson et al., 2014). Its role is not only associated with the information and knowledge that it spreads among learners, it also includes the institutions teaching approaches, policies and bylaws Robinson et al., 2014). However, budgets for public education allocated by governments continue to decline over the years, while the public's expectations for the performance of these educational institutions rise. This conflict puts many of these institutions in a tough position as they try to accomplish more developments with less cost (Wiley et al., 2012). One of the major challenges these institutions face is the increasing costs of textbooks where textbook is thought more costly than tuition fees (Illowsky et al., 2016). For example, the study conducted by Hilton et al. (2014) indicated that the average textbook price was $\$ 90.00$ at seven different institutions across a variety of general education courses in the US, including science, mathematics, humanities, and business disciplines. In another study that surveyed 22,129 students in Florida, the results revealed that $64 \%$ of the students claimed that they did not buy the necessary textbooks due to its high cost. Almost half of students in the same research replied that the high expense for textbooks caused them to register fewer courses, and a third of them claimed that they had gained a low grade because they were not able to purchase the required textbooks (Florida Virtual Campus, 2012).

Such high increases in the costs of textbooks have encouraged many educational institutions to develop and adopt open textbooks (OT) as an alternative to traditional textbooks and make them freely available for users (Wiley et al., 2012; Illowsky et al., 2016). Open textbooks are part of open educational resources (OER) that are available to students in a variety of digital formats at no cost (Jhangiani et al., 2018). They are considered as an important part of the fast development of increasing accessibility in higher education (Johnson et al., 2010). They provide an alternative to commercial textbooks for educators, allow students and educators with permissions given under open licenses, and lower student expenses (Belikov \& McLure, 2020). By making e-books as part of open educational resources, universities are increasing its accessibility where faculty and students can reuse and modify them based on their needs (Hilton, Lutz, \& Wiley, 2012). Hence, open textbooks are important for higher education systems because they allow students to access free material online (Ozdemir \& Hendricks, 2017) and offer educators the opportunity to have control over instructional resources where they can use, revise and remix them in new ways that suit their teaching purposes (Baker \& Hood, 2011; Hodgkinson-Williams, 2014; Farrow, 2017; Algers, 2020).

As a result, many higher education institutions initiated research projects to address the affordability of textbooks for 
educators and students. In a study done by Pitt (2015) surveyed 127 faculty members who were using open textbooks in their courses. The study found that the majority of the academic staff perceived its use positively and that they preferred to continue using them because of its flexibility for adaptation. Prasad and Usagawa (2014) from the University of South Pacific in America conducted another study to assess the faculty willingness to develop open textbooks for their courses. The findings of their study indicated that the faculty were willing to develop open textbooks for their courses because of cost saving and free accessibility. Similarly, the studies done by (Jhangiani \& Jhangiani, 2017; Jhangiani, Pitt, Hendricks, Key, \& Lalonde, 2016; Kimmons, 2015; Bliss, et al., 2013), results showed that most of the educators and students were comfortable using open textbooks over traditional textbook because it saved them costs and allowed them online accessibility.

At the College of Education in Sultan Qaboos University in Oman, where this study is taking place, open textbooks and OER are still a new concept. Thus, it is thought that doing a study to investigate the faculty perspectives on their uses and perceptions of open textbooks is important because it will present additional data drawing on the feedback from the SQU academic staff. This study does not follow a specific conceptual framework and therefore, it is done in a form of descriptive survey which is thought adequate to investigate SQU faculty perceptions in regard to OER at this stage. That is because this research area is still relatively new and requires more exploration. According to Loeb et al. (2017) descriptive studies do not follow a conceptual framework or a specific theory of learning. They include simple type of research tools for collecting data such as questionnaires and do not aim to develop a set of scientific actions. However, descriptive studies can offer valuable information about the problems being investigated and the solutions to be proposed for solving them (Loeb et al., 2017). Hence, this study aimed to investigate the different accessibility views in regard to open textbooks from the perspectives of SQU faculty. Specifically, the study tries to answer the following questions:

1. How do SQU academic staff perceive open book accessibility for use, compared to other print materials?

2. Is there any statistically significant differences between male and female faculty in the use of open books?

3. Is there any statistical significance differences between academic disciplines in the use of open books?

4. Is there any statistical significance differences between teaching experiences of faculty in the use of open books?

The paper starts with a literature review on previous work done on the academic staff uses and perceptions of open books. It is then followed by describing the methods used and discussing the results. Finally, concluding remarks and recommendations for future research are presented.

\section{LITERATURE REVIEW}

As the prices of print textbooks have risen dramatically, electronic textbooks became a more cost-effective choice for many universities, faculty and students (Fischer, et al., 2015). Over time, the open educational resources (OER) aim to address the financial difficulties connected with text and e- books as well as the capacity to deliver current, relevant knowledge in a flexible manner that is appropriate for how students learn. They make it possible for everyone to create affordable, universally available educational materials that could be used for teaching and learning (Hilton, 2016). An early proponent of the OER movement, the William and Flora Hewlett Foundation, defends open educational materials as "teaching, learning, and research resources that reside in the public domain or have been released under an intellectual property license that permits their free use and re-purposing by others. Open educational resources include full courses, course materials, modules, textbooks, streaming videos, tests, software, and any other tools, materials, or techniques used to support access to knowledge" (Hewlett, 2013).

As a result, a wide variety of OER have been created to replace traditional textbooks and to address the needs of the teachers and students to have free access to content that are usually accessible online and approved for open access (Jung, Bauer \& Allan, 2017). These OER typically have Creative Commons licenses that provide the legal permissions necessary to free share, modify, and reuse them (Hilton et al., 2016).

Further, open books can also provide support such as dictionaries, font color and size adjustment, text orientation, embedded reference links, and search capabilities that are not possible with print materials, offering learners an enhanced reading experience (Morales and Baker, 2018). Text-tospeech function offered with most e-reading software, allows users to click on words and hear pronunciation (De los Arcos et al., 2016). Finally, open textbooks often offer multilanguage support, increasing accessibility for non-Englishspeaking learners as well as access for faculty needing specific resources and references (Everard \& Pierre, 2014). The presence of open books makes sense in a university setting and therefore this research focused on how faculty currently are using open textbooks and their perceptions on their use.

Although of the advantageous features of open books that are mentioned above, it appears that still many issues exist in regard to its adoption. One of these issues is related to the awareness of the meaning openness. According to the report done by Allen \& Seaman (2014), most educators have never heard of OER. Another research done by Boston Consultancy Group (2015) found that although more than half of K-12 educators and administrators had heard of OER, they had little understanding of how to best use it in an educational setting. Hence, efforts such as workshops were made to bring awareness among faculty about OER open books and the advantages of substituting commercial textbooks with open books (OT) in order to attend to their teaching needs and students' learning (Allen et al., 2015).

Another issue with the adoption of OER open books is the quality. Instructors and students' opinions of the quality of open textbooks used in the classroom have been explored in various studies. Bliss, Hilton, Wiley, and Thanos (2013) surveyed students and instructors who used open textbook as an OER substitute to traditional textbooks in eight different classes at seven U.S. institutions. 41 percent of the participants rated the quality of the class open textbooks as important and said the open textbooks were substantially better than traditional textbooks. Another study done by 
Hilton (2016) examined nine research in which instructors and students expressed their opinions regarding the quality of open books through surveys. According to these surveys, nearly half of the instructors and students believed that open books are of equivalent quality to traditional textbooks, with a larger proportion of students and instructors indicating that open books were of higher quality than traditional textbooks. Further, California OER Council (2016), surveyed instructors and students who utilized open textbooks at the University of California, California State University, and California Community College systems. The majority of instructors stated that the open textbook utilized was of excellent quality. Some other studies focused on the features that open books should have to determine what instructors thought was crucial for OER's quality. According to the findings the study of Clements and Pawlowski (2015), most instructors want OER to feature multimedia, be accurate in content, fulfil preestablished curricular criteria, work well with their learning management system, and come from a trustworthy source. Whereas the study of Pitt (2015) indicated that the quality of OER is determined by how it help educators better adapt to the requirements of their students and make their teaching simpler.

Consequently, many initiatives emerged to stress the important of the quality of OER and the role open textbooks have in improving accessibility for students and faculty. One of these initiatives is the Open Textbook project funded by RMIT University which aimed to develop, support and promote open textbooks (Ponte et al., 2021). Siyavula was another initiative funded by South African government to produce open textbooks that are available online and are openly licensed, allowing teachers to freely use, modify, print, and share (Jimes et al., 2013). Kansas State University has also provided grants for faculty in an initiative to replace textbooks with open textbooks and make them available for students at no costs (Delimont et al., 2016). The BCcampus Open Textbook project by British Columbia, Open Textbook Library (OTL) project by the University of Minnesota, OpenStax project by Rice University, the Open SUNY Textbooks project by the State University of New York and many more are all initiatives to support faculty members to create and publish open textbooks that are accessible to all for free. Turkey's Open Courseware Consortium focuses on open educational resources. It translates the OER resources into Turkish for classroom usage from Pre-K through graduate degrees, and provides users with a network of volunteer professionals. The Consortium is made up of a number of Turkish universities and institutions.

All these initiatives and many more demonstrated that the accessibility of open books supports the availability of a variety of print formats to better serve the individualized needs of learners and instructors. Advantages include lowering textbook prices, increasing access to a variety of resources and allowing students better usability and readability (Bliss et al., 2013). As well, the ability to reuse and modify open textbooks is another characteristic of open textbooks that draws faculty to adopt using it (Everard \& Pierre, 2014). Such flexibility can allow creating materials that can be accessed outside classroom sessions and granting students access to these materials that are conventionally prohibited from removing from libraries or resource rooms, like rare maps, photos, and reference texts (De los Arcos et al., 2016).

Based on what has been discussed above, a review of the available literature shows that no study of faculty perceptions of open book usage in the context of Oman has been done. Hence, this study is critical for SQU scholars as it may provide other prospective about how Omani faculty staff perceive the use of open books. It is expected that the results of this research can help faculty staff in planning effective application of open book resources in SQU.

\section{Methodology}

To examine the uses and perceptions of open books by SQU academic staff, the study employed a similar survey which was used previously in a study investigating the uses and perceptions of e-books from the perspectives of SQU students (Al Saadi et al., 2017). The questions were reoriented, devolved and modified to adapt to the language and culture of the target group. The survey on the use and perceptions of open books by SQU academic staff included 27 questions. The first eight questions aimed at obtaining information about the demographic information of the respondents. The survey also contained questions about the definition of open books, its uses, purposes and frequency, its advantages and disadvantages. The last section contained the main questions of the survey, which requested the preference for the use of open books to print books, the reasons for its use and how the faculty imagine their future use. Six additional open questions were embedded throughout the survey to allow deeper answers and explanations on specific points. The survey was then uploaded to Google Forms in Arabic and English. The original survey with (AC) was validated by six faculty members from the SQU College of education. They evaluated the tool statements based on their clarity, correctness, significance, and relevance. Some changes were made based on their feedback, including wording and question additions, deletions, and reframing. The survey was then piloted with 30 instructors who were not included in the main investigation. The Cronbach's alpha coefficient was used to assess the dependability of the faculty' replies. "Reliability varies between 0.00 and 1.00 and should be at least 0.70 or, preferably, higher" (Fraenkel \& Wallen, 2009 , p.154). The questionnaire's reliability was 0.925 , indicating that it has extremely excellent internal consistency dependability. Based on that, the tool was then adopted for this study. After that the survey was then designed in Google Forms and the link was then distributed to all SQU academic staff during the spring semester in 2020 through the university email. The results were then analyzed.

\section{Results}

This study investigated SQU faculty's uses and perceptions of open textbooks by distributing a faculty survey during the spring of 2020 to eight colleges and the Language Centre at SQU. Data was collected from 135 faculty members who took part in the research. In the total number of the participants, $57.25 \%$ were male, which contributed to the largest number, while the female was $42.75 \%$. On the 
probability of using an open book, $86.96 \%$ responded to have used an open book in one activity or another, while the rest, $13.02 \%$, claimed to have never interacted with an open book. Based on the survey results, different faculty members had different definitions of what open books are, though they all fall to close definition since they all are electronically available documents; this includes any reading material that is used in the coursework that is electronically available regardless of the device reading it (van Gerven Oei, 2019). On interacting with open books, the highest percentage used laptops followed by desktops at $75 \%$ and $60.83 \%$, respectively.

Determination of the use of open books for use by faculty at SQU, the age of the participants involved in the study is vital to consider. As shown in the table below, the least participants involved were above 60 years, followed by those between 22-30 years, contribute to $7.97 \%$ and $11.59 \%$, respectively. The largest group of the participants involved in the study involved faculty members ranging between $31-60$ years who contributed to the largest number of participants in the study (Fry, 2020).

TABLE I: AGE AND STATISTICS OF THE FACULTY MEMBERS INVOLVED IN THE RESEARCH AT SQU

\begin{tabular}{cccc}
\hline \hline & Age & Percentage & Frequency \\
\hline 1 & $22-30$ & $11.59 \%$ & 16 \\
2 & $31-40$ & $23.91 \%$ & 33 \\
3 & $41-50$ & $27.54 \%$ & 38 \\
4 & $51-60$ & $28.99 \%$ & 40 \\
5 & $60+$ & $7.97 \%$ & 11 \\
\hline \hline
\end{tabular}

Further, the consideration of using open books does not greatly vary depending on the college or the center. The participants are from nine colleges and the Language Centre at SQU, and the comparison in the use of open books depending on college ranges between $6.52 \%$ and the highest being $19.57 \%$. Considering the language center, it is noticed to have the largest use of open books followed by the education college with $19.94 \%$. The lowest users of open books are the law college with $0.0 \%$, followed by the engineering college with $6.62 \%$.

\begin{tabular}{cccc}
\multicolumn{4}{c}{ TABLE 2: COLLEGE OR CENTER FOR PARTICIPANTS ON RESEARCH } \\
\hline \hline \multicolumn{2}{c}{ College/ Center } & Percentage & Frequency \\
\hline 1 & Agriculture & $7.97 \%$ & 11 \\
2 & Arts and & $14.49 \%$ & 20 \\
& Social Studies & & \\
& Economy and & & 15 \\
3 & Political & $10.87 \%$ & \\
& Sciences & & 22 \\
4 & Education & $15.94 \%$ & 9 \\
5 & Engineering & $6.52 \%$ & 0 \\
6 & Law & $0.00 \%$ & 10 \\
7 & Medicine & $7.25 \%$ & 13 \\
8 & Science & $9.42 \%$ & 11 \\
9 & Nursing & $7.97 \%$ & 27 \\
10 & Language & $19.57 \%$ & \\
\hline \hline
\end{tabular}

Through the research, the faculty members preferred the use of open books to the printed books. As indicated in Table $3,45 \%$ of the faculty members preferred open books, while $31.67 \%$ preferred printed books. However, $23.33 \%$ had no preference. Throughout the study, students' comfort in using the open books concerning the printed books; $68.33 \%$ preferred open books while $31.67 \%$ did not feel comfortable using the open books. The comfort of the students in using open books is a great consideration to determine the urgency of the faculty to apply the resource in their daily classroom teaching (Dewi et al., 2020).

TABLE 3: EFFECT OF ACADEMIC RANK TO THE USE OF OPEN BOOKS IN THE

\begin{tabular}{|c|c|c|c|}
\hline \multicolumn{4}{|c|}{ FACULTY } \\
\hline & ademic rank & Percentage & Frequency \\
\hline 1 & Demonstrator & $2.17 \%$ & 3 \\
\hline 2 & Lecturer & $31.16 \%$ & 43 \\
\hline 3 & $\begin{array}{l}\text { Assistant } \\
\text { Professor }\end{array}$ & $38.41 \%$ & 53 \\
\hline 4 & $\begin{array}{l}\text { Associate } \\
\text { Professor }\end{array}$ & $13.04 \%$ & 18 \\
\hline 5 & Professor & $5.07 \%$ & 7 \\
\hline 6 & $\begin{array}{l}\text { Other (please } \\
\text { specify): }\end{array}$ & $10.14 \%$ & 14 \\
\hline
\end{tabular}

Academic rank is also a factor that was noticed to greatly affect the use of open books among the faculty. As recorded in table 4, the Assistant professors led open books seconded by lecturers, with $38.41 \%$ and $31.16 \%$, respectively. Demonstrators recorded the lowest use of open book materials, with professors close with $2.17 \%$ and $5.07 \%$, respectively.

TABLE4: PREFERABILITY OF THE TEXT FOR TEACHING IN RESPECTIVE

\begin{tabular}{lcc} 
& COURSES & \\
\hline \hline $\begin{array}{c}\text { Thinking about the } \\
\text { texts required for } \\
\text { teaching your } \\
\text { course(s), would } \\
\text { you prefer to use } \\
\text { an open book or a } \\
\text { printed book? }\end{array}$ & Percentage & Frequency \\
\hline $1 \quad$ Open book & $45.00 \%$ & 54 \\
$2 \quad$ Printed book & $31.67 \%$ & 38 \\
$3 \quad$ No & $23.33 \%$ & 28 \\
\hline \hline
\end{tabular}

There is great support by the university in the availing of the open books where $63.33 \%$ of the faculty got their open book materials used for teaching from the university elibrary. Many faculty members got open book materials from publishers and social networking sites, which illustrates that other faculty who network with them have access to open books that greatly aid teaching. Many respondents prefer open books due to their ability to have linked chapters where it is easier to jump to a specific chapter with ease. The respondents claimed the availability of open books to have search tools that allow them to search key contents throughout the book which is a factor that contributes to the preference of the open book.

TABLE 5: RELATIONSHIP BETWEEN TEACHING EXPERIENCE CONCERNING THE USE OF OPEN BOOK IN THE FACULTY

\begin{tabular}{cccc}
\hline \hline $\begin{array}{c}\text { Teaching } \\
\text { experience (in } \\
\text { years) }\end{array}$ & Percentage & Frequency \\
\hline 1 & $0-5$ & $17.39 \%$ & 24 \\
2 & $6-10$ & $15.94 \%$ & 22 \\
3 & $11-15$ & $16.67 \%$ & 23 \\
4 & $\begin{array}{c}\text { More than } \\
4\end{array}$ & $50.00 \%$ & 69 \\
\hline \hline
\end{tabular}

The respondents who use open books are more as their experience increases over years. Those who have been 
teaching for more than 15 years were seen to use open books more as they had a $50 \%$ of the total respondents. The respondents with fewer years of experience use open books less in their teaching. Respondents between 6-10 years of experience are noted to have the least percentage in using open books with a 15.94 percentage. separate compound units, e.g., "A·m".

\section{DISCUSSION}

This study's results highlight several important points of discussion concerning the uses and perceptions of open books by faculty here at Sultan Qaboos University. Most faculty define open books in the largest terms possible which could indicate their flexible approach to considering different versions of open books made available. The technological advancement is a great factor that has contributed to their perceptions. As noticed in the results of the respondents, most of the faculty members accessed open books via laptops, desktops, mobile phones and other open book reading materials such as Kindle, Nook, and Kibo. As well, the university e-library is one of the sources where open books are accessible for use by the faculty and open books are easily available to them where some stated they receive open books from social sites. With the majority of faculty reporting to use open books in their teaching and research, the open book initiative of increasing their use seem to serve the existing resource market at the university. As evidenced by prior research (Bliss et al., 2013), the majority of SQU faculty reported a positive experience using open books with the largest advantage by far being the accessible nature of the digitized format. That shows the importance of accessibility for the university resources has already been stressed and is reinforced by the faculty's responses. The faculty recognize however, that they need the training on the use of electronic resources in teaching.

Throughout the study carried out at SQU, more males took part in the research, where $57.25 \%$ were male, and $42.75 \%$ were female. Throughout the research, there is no statistical significance that shows that open books are affected by gender. However, the use of open books is greatly affected by other factors such as the type of programs the faculty members are teaching at the university. Technology' faculty seem to prefer open books $(70.29 \%)$, while those teaching Diploma courses do not $(8.70 \%)$. This finding is in line with the study results done by Robinson, et al (20015) who examined whether students' learning was influenced by their instructors' adoption of open textbooks instead of traditional publisher produced textbooks. The results showed that positive gains for students using the open chemistry textbooks compared to students studying earth systems and physics courses. Hence, the use of open books may depend on the availability of electronic devices, which in some instances may not always be available for use. There are many advantages to using open books though some faculty members would vary using open books and printed books with different situations. Printed books may be used by faculty members to ensure their students read the entire content and not move to a particular piece of information by using the search tools available in the open books.

Through the research, academic disciplines were noticed not to have a great deviation in use of open books. It is noticed that the language Center had the lead in using open books with a $19.57 \%$; the use of open books by the language Center is explained by the fact that many language journals are available in online formats and its content is understood by the language professionals.

Through engagements, the language Center is favored by using open books where the professionals are not required to stack loads of books, but just carry them all on their electronic devices. The use of open books does not apply to law faculty members, with a $0.0 \%$. The materials used by law departments are known to mainly exist in printed formats and not in electronic formats.

Teaching experience is a factor that is greatly affecting the use of open books. As indicated in the findings, there are more use of open books in the teachers of the bachelor and masters than those of Diploma courses. The bachelors had a $70.29 \%$, while the diploma had an $8.70 \%$ preference for Open books. The more experienced teachers are noticed to prefer use of open books in their course. That might be associated to their familiarity with open access textbooks. Allen and Seaman (2014) found that just 34\% of respondents expressed awareness of OER in their nationally representative surveys of 2144 academic members in the United States. Different reasons such as writing notes on the printed books were given for not using the open books. The faculty members who participated in the survey explained that the notes written in the printed books might be used for further understanding. Some open books are only leased and not completely sold out; this is an advantage where the books may be taken back after a while once the lease expires.

Printed books and journals have been in use for many years compared to open books, which have begun after the advancement in technology. At SQU, some faculty members would prefer open books interchangeably with the printed materials depending on the availability and the course being handled. Open books have been embraced at the university, where the university has an e-library that facilitates the posting of learning materials on the dashboards of different departments for study during online learning sessions. With the increased application of online learning in the university, open books are greatly helpful to faculty and students. They can refer to different materials from different regions, and there is no fear of losing an open book as it may happen with the printed books. This finding is similar to previous research on open online resources as compared to traditional print ones (e.g., Hilton, 2016; Grissett \& Huffman, 2019).

As noticed in the study, as the use of open books continues to spread, it is visible that their presence cannot be ignored and how they play an important role in the studies. The choice of appropriate titles of the open books greatly determines the application of the materials when it comes to their study. The research is important to the SQU since it clearly shows the application of open books in different areas in the faculty. Due to the increased application of the Open books, more investment needs to be carried out on the open books and to ensure the materials are more available for faculty members (Ozdemir \& Hendricks, 2017).

Finally, it is worth mentioning that the ability to ask the academic staff such questions is a good chance for universities to start evaluating open educational resources. As 
noted by Jung, Bauer and Allan (2017) that since any text book is used or produced can easily be revised, reused and redesigned on locally, the perceptions of the academic staff can be easily used to provide a true and meaningful improvement of the open text books needed to be included in the taught courses. In contrast, the questions that are placed in traditional textbooks would necessarily be purely academic, as copyright restrictions would forbid the possibility to make significant changes to these materials.

\section{CONCLUSION}

Since users' preferences are always changing, it's important for future open book initiatives to be aware of consumption patterns. As of right now, this study indicates that open books complement and coexist with the print textbooks. In other words, perhaps the strongest takeaway from this study is that, much like the students, SQU academic staff have embraced both open books and print books with positivity that continues at present. When SQU academic staff realize that e-books are beneficial for their research activities and students' learning and that it will help them enhance their course performance, they will begin to utilize them more frequently. As well, if open books use is being enthusiastically put forward by the university, it is hoped that the results of this study will help to inform their decisions and the kinds of supports that need to be put in place to make the open book initiative a success. Further research is needed to answer essential questions related to this field of research. Future studies could look at, for example, whether increasing accessibility to more OER materials might offer academic staff more opportunities to be creative in developing better online courses and grant their students access to other OER resources that might lead to more student learning. Other research could also consider developing own OT to be a good move forward for the OER OT in Oman.

\section{CONFLICT OF INTEREST}

The author declared no potential conflicts of interest with respect to the research, authorship, and/or publication of this article.

\section{REFERENCES}

Allen, I. E. and J. Seaman (2014). Opening the Curriculum: Open Educational Resources in US Higher Education, Babson Survey Research Group. Retrieved from https://files.eric.ed.gov/fulltext/ED572730.pdf.

Algers, A. (2020). Open Textbooks: A Balance Between Empowerment and Disruption. Tech Know Learn 25, 569-584 (2020).

Allen, G., Guzman-Alvarez, A., Molinaro, M., \& Larsen, D. (2015). Assessing the impact and efficacy of the open-access. ChemWiki textbook project. Educause Learning Initiative Brief. January 2015

Baker, J., \& Hood, J. (2011). Things you should know about Gosling Publishing. Retrieved from

http://affordablelearningok.org/uploads/WH/Q4/WHQ4xTVjvdCxIix ua3oHVw/Educause-Open-Textbook-7-things.pdf.

Barnes, C. (2007). Disability, higher education and the inclusive society. British Journal of Sociology of Education, 28(1), 135-145

Belikov, O. and M. McLure (2020). A Qualitative Analysis of Open Textbook Reviews. The International Journal of Open Educational Resources 3(2): 25066.
Bliss, T., Hilton, J., Wiley, D., \& Thanos, K. (2013). The cost and quality of online open textbooks: Perceptions of community college faculty and students. First Monday, 18(1).

California Open Educational Resources Council. (2016). White paper: OER adoption study. Retrieved from http://tinyurl.com/WPOERAdoption040116

Clements, K., J. Pawlowski, et al. (2015). Open educational resources repositories literature review-Towards a comprehensive quality approaches framework. Computers In Human Behaviour, 51: 10981106.

Chapman, V. (2008). Developing inclusive curricula, Learning and Teaching in Higher Education, 3, 62-89.

Cummins, J. Brown, K., \& Sayers, D. (2007). Literacy, Technology, and Diversity: Teaching for Success in Changing Times. Boston, USA: Pearson.

Cynthia Jimes, Shenandoah Weiss, Renae Keep (2013). Addressing the Local in Localization: A Case Study of Open Textbook Adoption by Three South African Teachers. Journal of Asynchronous Learning Networks, 7(2), 73-86.

Dewi, R., Mujiyanto, J., Rukmini, D. and Saleh, M., (2020). The Relation Between Formulaic Expressions Fluency and Proficiency of Indonesian EFL College Students Using Open book Instructions Via Edmodo. International Journal of Psychosocial Rehabilitation, 24(1), pp.1030-1043.

Doering, T., Pereira, L. \& Kuechler, L. (2012). The use of e-textbooks in higher education: A case study. E-Leader Berlin.

Everard, A., \& St Pierre, K. (2014). A case for student adoption of open textbooks. Journal of the Academy of Business Education, 15, 66-76.

Farrow, R. (2017). Open education and critical pedagogy. Learning, Media and Technology, 42(2), 130-146.

Fischer, L., Hilton, J., Robinson, T.J. et al. (2015). A multi-institutional study of the Impact of Open Textbook Adoption on the Learning Outcomes of Post-secondary Students. J Comput High Educ. 27, 159-172.

Hewlett (2013). Open educational resources. http://www.hewlett.org/programs/education-program/openeducational-resources

Jobrack, B. (2011). Tyranny Of The Textbook: An Insider Exposes How Educational Materials Undermine Reforms. Lanham, MD: Rowman \& Littlefield.

Fry, A., 2018. Factors Affecting the Use of Print and Electronic Books: A Use Study and Discussion. College \& Research Libraries, 79(1).

Florida Virtual Campus. (2012). 2012 Florida student textbook survey. Tallahassee, FL. Retrieved from

http://www.openaccesstextbooks.org/pdf/2012_Florida_Student_Text book_Survey.pdf

Fry, A., 2020. Use Patterns For Open Books: The Effects Of A Subject, Age, And Availability On Use Rate. The Journal of Academic Librarianship, 46(3), p.102150.

Gonzalez, R., Gasco, J. \& Llopis, J (2014). Ict in higher education: an experience with e-books. Applied Computer Science, 10 (1), 1-10.

Grissett JO, Huffman C. (2019). An Open versus Traditional Psychology Textbook: Student Performance, Perceptions, and Use. Psychology Learning \& Teaching, 18(1):21-35.

Hilton III, J., Lutz, N. \& Wiley, D. (2012). Examining the Reuse of Open Textbooks. International Review of Research in Open and Distributed Learning, 13 (2), 45-58.

Hilton, J. (2016). Open educational resources and college textbook choices: a review of research on efficacy and perceptions. Education Tech Research Dev, 64, 573-590.

Hilton III, J. L., Fischer, L., Wiley, D., \& William, L. (2016). Maintaining Momentum Toward Graduation: OER and the Course Throughput Rate. The International Review of Research in Open and Distributed Learning, 17(6).

Illowsky, B., Hilton III, J., Whiting, J., \& Ackerman, J. (2016). Examining Student Perception of an Open Statistics Book. Open Praxis, 8(3), 265276.

Jhangiani, R. S. and S. Jhangiani (2017). Investigating the perceptions, use, and impact of open textbooks: A survey of post-secondary students in British Columbia. The International Review of Research in Open and Distributed Learning, 18(4).

Jhangiani, R. S., Dastur, F. N., Le Grand, R., \& Penner, K. (2018). As Good or Better than Commercial Textbooks: Students' Perceptions and Outcomes from Using Open Digital and Open Print Textbooks. The Canadian Journal for the Scholarship of Teaching and Learning, 9(1).

Jhangiani, R. S., Pitt, R., Hendricks, C., Key, J., \& Lalonde, C. (2016). Exploring faculty use of open educational resources at British Columbia post-secondary institutions. BCcampus. 
Johnson, L., Levine, A., Smith, R., \& Stone, S. (2010). Horizon report for the new media consortium and the EDUCAUSE learning initiative. Retrieved May 2018.

Jung, E., C. Bauer and Allan, H. (2017). Higher education faculty perceptions of open textbook adoption. The International Review of Research in Open and Distributed Learning, 18(4).

Loeb, S., Dynarski, S., McFarland, D., Morris, P., Reardon, S., \& Reber, S. (2017). Descriptive Analysis in Education: A Guide for Researchers (NCEE 2017-4023). US Department of Education, Institute of Education Sciences. National Center for Education Evaluation and Regional Assistance: 1-40.

Lovell-Simons, A. \& Kerr, S. (2011). E-books - a key to greater accessibility. In G. Williams, P. Statham, N. Brown \& B. Cleland (Eds.), Changing Demands, Changing Directions. Proceedings Ascilite Hobart 2011, 826-828.

McNaught, A. and Alexander, H. 2014. Ebooks and accessibility. In Woodward, H. (ed.) Ebooks in Education: Realising the Vision.pp. 3549. London: Ubiquity Press. DOI: http://dx.doi.org/10.5334/bal.e

Morales, R. and Baker, A (2018). Secondary Students' Perceptions of Open Science Textbooks. Journal of Interactive Media in Education, 1(4), pp. 1-9.

Mulholland, E. \& Bates, J. (2014). Use and Perceptions of e-books by academic staff in further education. The Journal of Academic Librarianship, 40, 494-499.

Nelson, M. R. (2008). E-books in higher education: nearing the end of the era of hype? Educause Review, 43(2), 40.

Delimonta, N., Turtleb, E., Bennettc, A., Adhikarid, K. and Lindshield, B. (2016). University students and faculty have positive perceptions of open/alternative resources and their utilization in a textbook replacement initiative. Research in Learning Technology, 24.

Ozdemir, O. \& Hendricks, C. (2017). Instructor and student experiences with open textbooks, from the California open online library for education (Cool4Ed). J Comput High Educ, 29, 98-113.

Pitt, R. (2015). Mainstreaming open textbooks: Educator perspectives on the impact of openstax college open textbooks. International Review of Research on Open and Distributed Learning, 16(4). Retrieved from https://www.proquest.com/scholarly-journals/mainstreaming-opentextbooks-educator/docview/1754593273/se-2?accountid=27575

Ponte, F., Lennox, A., \& Hurley, J. (2021). The Evolution of the Open Textbook Initiative. Journal of the Australian Library and Information Association, 1-19.

Prasad, D. \& Usagawa, T. (2014). Towards Development of OER Derived Custom-Built Open Textbooks: A Baseline Survey of University Teachers at the University of the South Pacific. International Review of Research in Open and Distributed Learning, 15 (4), 226-247.

Robinson, T., Fischer, L., Wiley, D., Hilton, J. (2014). The Impact of Open Textbooks on Secondary Science Learning Outcomes. Educational Researcher, 43(7), 341-351.

Robinson, Thomas J., (2015). The Effects of Open Educational Resource Adoption on Measures of PostSecondary Student Success. Theses and Dissertations. 5815. Retrieved from https://scholarsarchive.byu.edu/etd/5815

Rowlands, I., Nicholas, D., Jamali, H. R., \& Huntington, P. (2007). What do faculty and students really think about e-books?. Aslib Proceedings, 59 (6), $489-511$.

Shrode, F., 2013. Environmental Information Sources: Websites and Books. Electronic Green Journal, 1(34).

Slater, R. (2010). Why aren't e-books gaining more ground in academic libraries? E-book use and perceptions: A review of published literature and research. Journal of Web Librarianship, 4, 305-331.

Ulman, J.G. (2005). Making Technology Work for Learners with Special Needs. Boston, USA: Pearson.

Van Gerven Oei, V. W. J. (2019). Transitioning Punctum Books to Open Source Infrastructure. Punctum Books. Retrieved from https://doi.org/10.21428/ae6a44a6.ada1a146

Wiley, D., Hilton III, J. L., Ellington, S., \& Hall, T. (2012). A preliminary examination of the cost savings and learning impacts of using open textbooks in middle and high school science classes. The International Review of Research in Open and Distributed Learning, 13(3), 262-276. 